\title{
A Language Reinforcement Program: ¡10 minutos!
}

\section{Un programa de reforzamiento de la lengua: ;10 minutos!}

Karen McMullin. Department of Modern Languages and Literatures. Trent University José Miguel García Ramírez. Department of Social Psychology. University of Granada.

Recepción: 13 de febrero de 2015 | Revisión: 13 febrero de 2015 | Aceptación/Publicación: 13 de febrero de 2015 Revisores: Jory Bolton. Trent University

Marzia Fiorini. Grupo de Investigación: Aprendizaje y Desarrollo en Contextos Educativos. Universidad de Granada Correspondencia con los autores: karenmcmullin@trentu.ca | miguelgr@ugr.es

\begin{abstract}
¡10 minutos! is a program designed as a voluntary extra-curricular activity for students taking Spanish language courses who wish to practise and reinforce the lexical and grammatical constructions presented in class and in the textbook. The program began as a short daily email correspondence between students enrolled in the introductory-level Spanish course and the instructor, and has developed into a series of short, daily, conversation sessions between beginning students of Spanish and upper-year students of Spanish. The focus is on the use of meaningful language in everyday communication as well as the constancy of a simple daily activity that encourages students to focus on the language.
\end{abstract}

Keywords: Communicative Competence | Communicative Interaction

\section{Resumen}

¡10 minutos! es un programa diseñado como actividad extra-curricular voluntaria para los estudiantes que estudian los cursos de español y que desean practicar y reforzar las construcciones léxicas y gramaticales presentadas en clase y en el libro de texto. El programa comenzó como una breve correspondencia diaria por correo electrónico entre los estudiantes matriculados en el curso de español de nivel introductorio y el instructor, y se convirtió en una serie de sesiones cortas de conversación diarias entre los estudiantes principiantes y estudiantes avanzados de español. Se centra en el uso del lenguaje significativo en la comunicación cotidiana, así como la constancia de una actividad diaria simple que anima a los estudiantes a pensar en la lengua.

Palabras clave: Competencia Comunicativa | Interacción Comunicativa

\section{Introduction}

Learning another language is becoming increasingly more important in our society. Academically, the process of learning a new language requires effort from both the teacher and the student in order to attain greater competence. Second language teachers need to put to use certain tools that will help them successfully present the teaching material. The application of the Communicative Approach helps teachers to motivate their students to gain confidence as well as competence in communicating in the target language. The use of the communicative approach in developing communicative competence, building on students' current knowledge, contextualizing communication and the importance of meaning in language learning are concepts taken into account during the development and implementation of the language reinforcement program i10 minutos! This extracurricular program serves to help 
reinforce grammar and vocabulary learned by students enrolled in first and second year Spanish courses at Trent University (Canada).

\section{Benefits and challenges of learning a language}

There are many reasons for deciding to study a second language. We live in a period of globalization, where there is a continuous movement of people and information around the world. In 1996 a study was conducted in that Spanish was found to be the third most commonly used language in the world. Spanish has spread beyond its Latin American and European boundaries into almost every other part of the world. That being said, Spanish is a language that is well worth the effort to learn and eventually master. The choice to study another language can have a great effect on one's life (Fishman, 1998). Achieving communicative competence in the Spanish language can provide unique career options and opportunities for advancement within that career.

In a study performed in the United States it was found that learning a second language contributed greatly to the intellectual development of the students (Alanis, 2000). Another study performed in Spain showed that learning a second language tended to increase the academic standing of the students while at the same time helped them to be more accepting of people of different races and ethnic groups (Ramos, 2007). Overall, there are numerous academic, social and career benefits of speaking another language.

These benefits for the students who choose to learn a second language help to motivate them. However, learning a new language also presents challenges as much for the students as for the teacher. In order for students to attain autonomy in the process of acquiring communicative competence in the target language, a considerable effort is required. Second language teachers have the responsibility of presenting the information needed to help students develop this competence and of maintaining their initial motivation while guiding them through the process. It is important for them to make note of the reasons that students decided to study the language. Knowing the goals and motives of the students will help the professor to be able to encourage the students to develop communicative competence in the target language.

Students are motivated in different ways and teachers should be aware of the different ways that students are motivated and attempt to teach in a way that keeps students engaged and motivated to learn not only in the classroom but outside of the classroom (Garcia-Ramirez, 2014; Fiorini, Garcia-Ramirez, 2013). Teachers should use activities and assignments that provide the opportunity for students to gain a broader communicative competence and interaction.

Although second language teachers can play a significant role in students' ability to succeed in learning the second language, the ability of the students to motivate themselves is of greater importance since their motivation to learn continues outside the classroom. The classroom has limits with respect to the quantity and quality of competence that can be achieved (Muñoz, 2000). For this reason, each student must do his/her part to achieve competence in the target language.

\section{¡10 Minutos!}

With these ideas in mind, $; 10$ minutos! was initiated as a pilot Project by the Social Psychology department at the University of Granada (Spain). It is a voluntary activity 
designed to complement the classroom activities and to practise and consolidate the skills and knowledge acquired in the Spanish language courses at Trent University.

The original program consisted of a daily interaction by email between students taking the introductory Spanish course and the instructor. Each day the instructor sends the students a short email message containing a comment or statement followed by a series of questions directly related to the content and structures previously presented and practised in class. The messages are designed so that reading, understanding and answering the questions takes approximately 10 minutes. In this activity, the importance lies not in the complexity of the task, but rather in the use of authentic language embedded in the real-life context of everyday communication using an electronic platform that the students are familiar and comfortable with.

Another very important aspect is the constancy of the program. Every day the students receive an email in Spanish, which they are free to read at their leisure and to answer without feeling any sort of pressure. Receiving a message in Spanish each day (even if they decide not to answer the questions), encourages the students to focus their attention on the language.

Although the questions are written, the content and format are conversational, so that the students practise both conversational skills and written accuracy. The content and structure of the initial statements are also conversational, but being slightly above the current level of the students, serve both as an example and as a form of motivation since with a minimum of study, effort and practise, the students are able to replicate the example using their own words and personal situation. In this way the language and structures are both contextualized and meaningful, personalized and transferred from the context of the classroom to real communication outside of the classroom.

These same principals are applied in the second phase of the program which was developed and implemented by Spanish faculty (Trent University) with funding provided in the form of a Learning Innovations Grant by the Instructional Development Centre at Trent University. This phase of the program consists of short daily conversations between students enrolled in the Introductory-level Spanish courses and upper-year students of Spanish with an advanced level of knowledge and competence who act as conversation leaders or facilitators.

During these sessions the beginning students practise the vocabulary and grammar learned in class with the help and encouragement of the facilitators. The sessions take place on campus at one of the cafeterias or the library and it is this informal setting as well as the collaboration and encouragement of a peer who has already achieved an advanced level of competence in the target language that helps to increase the selfconfidence as well as the communicative competence of the beginning students, motivating them to continue to dedicate the time and effort required to achieve their goals.

The constancy of the program is also important. The students meet ideally five days per week and, although the frequency of the sessions may between one and five meetings per week, being aware that they have these sessions in addition to the regular classes encourages them to focus their attention on the language.

The participants of the program ¡10 minutos! are mainly students registered in the Introductory Spanish course at Trent University who attend the sessions for oral practice, grammar review and/or in order to improve pronunciation. The facilitators of 
¡10 minutos! make use of different practices and interactive exercises to successfully carry out the program creating a relaxed atmosphere of collaboration among peers and encouraging the students to practice by initiating conversations using the grammar and vocabulary learned in class.

The number of times that a participant attended a $¡ 10$ minutos! session varied from student to student. A few only attended once and had specific questions in mind while others attended frequently for an overall review of the Spanish language.

\section{Theoretical concepts}

Many learning theories and language teaching methods over the years have included the ideas of building on students' current knowledge while introducing new material, of contextualizing communication and the importance of meaning in the learning of languages.

Krashen's Monitor Theory consists of a series of hypotheses about second language acquisition. The Input Hypothesis states that students acquire language by being exposed to comprehensible input that is just beyond their present level. They are able to understand this input because familiar contexts are used and structures are acquired through meaningful communication. If sufficient communication is provided, acquisition continues. Also relevant is the Affective Filter hypothesis, which refers to the importance of optimal affective conditions in order for acquisition to take place. That is, when students are motivated and self-confident and anxiety is low. (Omaggio, 1993: 50)

¡10 minutos! provides meaningful input without the anxiety that some students might experience in a communicative classroom where oral communication is stressed. It allows students to practise material taught in class in a communicative setting while building on previous knowledge by adding new vocabulary or structures in a familiar context.

One of the basic principles of Chastain's Cognitive-Code Method states that the instructor must progress from the known to the unknown basing new material on the students' current knowledge of the target language. Another principle states that learning must be meaningful (Omaggio 1993:01). These concepts are reflected in both phases of the program.

Another approach describes language as an interactive process of communication. The Whole Language Movement uses activities that are meaningful to students and focuses on collaboration and communication with peers and with the teacher in constructing language (Richards \& Rogers 2001:109). ¡10 minutos! also focuses on collaboration and communication as the beginning students collaborate with the instructor (phase 1) or a conversation leader/facilitator (phase 2) to produce a meaningful conversation initiated by the instructor or facilitator and personalized by each student as he/she responds. This collaboration to improve the knowledge of the individual in the community is also one of the key concepts of Creative Knowledge (Fiorini \& Garcia-Ramirez, 2013).

¡10 minutos! is not a teaching method or approach but rather a practical application of some of these learning theories and principles in the form of a simple voluntary activity aimed at providing regular, interactive practice and reinforcement of vocabulary and structures presented in class. This practice helps the students to develop a good 
command of the language so that they can begin to use it correctly and comfortably in real communicative situations. In the words of Ellis (1992:102), "The purpose of practice is to activate the new knowledge to the point where it can be used automatically and correctly in normal communication ... practice is something that learners have to do in order to make the transition from knowing a feature to using it in real-life communication".

\section{Method}

\section{Participants}

The participants of this study were 162 students of the Introduction to Spanish course, 119 women and 43 men between the ages of 17 and $23(M=18.69 ; S D=1.89)$. These students participated voluntarily in the study.

\section{Procedure, Results and Observations}

The ¡10 minutes! program was implemented during 4 academic sessions from 2010/11 to $2013 / 14$ at Trent University.

In analyzing the evaluations of the students who participated in the $¡ 10$ minutos! program we observed that the regular participants showed increased self-confidence and ability in speaking in Spanish. Self-confidence is an important factor in being able to learn a new language and at the same time helps the student in developing communicative competence.

We observed that the students who had more self-confidence were also the ones that strove to put into practice what they had learned. During the first session of the program, many participants spoke very little in Spanish. After various sessions the participants began to gain confidence and began speaking more and more in the target language. Furthermore, they began to try forming more complete and more complex sentences.

Another observation was that the frequency in which students chose to participate impacted greatly the progress of the students. It was found that the students who participated more frequently in ¡10 minutos! improved much more than those who attended only a few sessions.

It was observed that ten minutes in some cases was not a sufficient amount of time to help students to have the full benefit of the program. Some participants came with questions about points of grammar that required more time to explain. In those cases the length of the sessions was adjusted in order to suit the needs of the participants. There were also special cases where students participated in only one session in order to clear up questions they had in preparation for a test or exam. In those cases, one session was sufficient time to help them be prepared.

Timing was certainly an issue in the program, both the frequency of sessions and the length of sessions. However, we also observed that the personal effort of each participant greatly affected the progress and development of their communicative competence. 


\section{Conclusions}

At the end of the academic years during which we implemented the program $; 10$ minutos! it was concluded that self-confidence is key in the process of learning a new language. Learning a foreign language can cause frustration in many students. To help the participants surpass any frustration and to increase their self-esteem a facilitator can begin at a basic level and advance according to the progress of the student. Each person has his/her own learning style and strategies; therefore it is necessary to vary the activities not only to develop oral competence but also reading and writing competence of the student.

The program ;10 minutos! benefits all of the participants, both the beginning Spanish students and the facilitators, improving the communicative competence of the two parties. While creating a lesson plan for the sessions the facilitators are able to review the structures and vocabulary that they will be helping the participants to understand and use correctly, which deepens and solidifies their own knowledge and understanding of the language.

¡10 minutos! is an innovative program that continues to be implemented in the teaching and learning of Spanish as a foreign language at Trent University. The aim of the activities performed in the sessions is to promote communicative competence in reading and writing but more especially in speaking. The results showed that participation in the program increases the self-confidence of the participants in addition to aiding in the development of communicative competence.

\section{References}

Alanis, I. (2000). A Texas two-way bilingual program: Its effects on linguistic and academic achievement. Bilingual Research Journal, 24(3), 225-248. http://dx.doi.org/10.1080/15235882.2000.10162763

Ellis, R. (1993). Second Language Acquisition and Language Pedagogy. Clevedon: Multilingual Matters. ISBN 13:9781853591365

Fiorini, M., García-Ramírez, JM. (2013). Cap. 5: Técnicas de grupo y creatividad aplicadas en el ámbito universitario, 117-147. En M.D. Villena Martínez, MD., A. Muñoz García, A. (2013). Recursos para la tutoría en el aula universitaria. Granada: Editorial Universidad de Granada. ISBN 13: 9788433855626.

Fishman, J. (1998). The New Linguistic Order. Foreign Policy, 113, 26-40. http://dx.doi.org/10.2307/1149230

Garcia-Ramirez, J.M. (2014). Selección de indicadores para la evaluación de la excelencia docente en la Universidad de Trent (Canadá). Granada: Universidad de Granada, 2014. http://hdl.handle.net/10481/30350

Muñoz, C. (2000). Segundas lenguas. Adquisición en el aula. Barcelona: Ariel Lingüística.

Omaggio, A. (1993). Teaching Language in Context. Boston: Heinle \& Heinle Publishers.

Ramos, F. (2007). Opiniones de alumnos de un programa bilingüe andaluz sobre su programa y sobre el bilingüismo. Revista Electrónica de Investigación Educativa, 9(2), 1-15. http://www.redalyc.org/articulo.oa?id=15590203 
Richards, J.C., and T.S. Rodgers. (2001). Approaches and Methods in Language Teaching. Cambridge: Cambridge University Press.

Citar:

McMullin, K., Garcia-Ramirez, JM. (2015). A Language Reinforcement Program: ¡10 minutos!. ReiDoCrea, 4, 28-34. http://digibug.ugr.es/handle/10481/33685

http://www.ugr.es/ reidocrea/ReiDoCrea-Vol.4-Art.4-McMullin.pdf 